\title{
Synthesis and Characterization of Fluorescent Copolymer Containing Rare Earth Metal Complex and Its Interaction with DNA
}

\author{
XIAO-XI HU, ${ }^{1,2}$ PENG-HUI LI, ${ }^{1,2}$ KELVIN W. K. YEUNG, ${ }^{2}$ PAUL K. CHU, ${ }^{3}$ SHUI-LIN WU, ${ }^{1,3}$ ZU-SHUN XU ${ }^{1,2,3}$ \\ ${ }^{1}$ Faculty of Materials Science and Engineering, Ministry-of-Education Key Laboratory for the Green Preparation and Application \\ of Functional Materials, Hubei University, Wuhan 430062, People's Republic of China \\ ${ }^{2}$ Division of Spine Surgery, Department of Orthopaedics and Traumatology, The University of Hong Kong, \\ Pokfulam, Hong Kong, China \\ ${ }^{3}$ Department of Physics \& Materials Science, City University of Hong Kong, Tat Chee Avenue, Kowloon, Hong Kong, China
}

Received 14 April 2010; accepted 21 September 2010

DOI: $10.1002 /$ pola. 24413

Published online 8 November 2010 in Wiley Online Library (wileyonlinelibrary.com).

\begin{abstract}
A complex of $\mathrm{Eu}^{3+}$, acrylic acid (AA), and 1, 10-phenanthroline (Phen) was synthesized. The structure and fluorescence of $\mathrm{Eu}(\mathrm{AA})_{3}$ Phen was characterized with elemental analysis, FTIR, ${ }^{1} \mathrm{H}$ NMR, and fluorescence spectroscopy. A novel copolymer containing rare earth complex, poly(PEGMA-co-NIPAm-co-Eu(AA)3Phen) (PPNEu), was prepared by free radical copolymerization in methanol with azodiisobutyronitrile as initiator. ${ }^{1} \mathrm{H}$ NMR, fluorescence spectroscopy, UV-vis spectroscopy, and TEM were used to characterize this copolymer. The interaction of PPNEu with deoxyribonucleic acid (DNA) was studied by fluorescence spectroscopy, UV-vis spectroscopy and agarose gel electrophoresis. The results of fluo-
\end{abstract}

rescence, UV-vis absorption, and agarose electrophoresis indicated that the PPNEu could interact with DNA in an electrostatic bonding mode. The TEM observation showed that the PPNEu could form spherical micelles in water solution small than $100 \mathrm{~nm}$; the efficient complexation of PPNEu with DNA occurred. These results suggested the potential of the PPNEu as gene detective reagent and gene delivery carrier. (c) 2010 Wiley Periodicals, Inc. J Polym Sci Part A: Polym Chem 48: 5961-5967, 2010

KEYWORDS: biomaterials; DNA; fluorescent copolymer; functionalization of polymers; luminescence; rare earth
INTRODUCTION Recently, great interest has been focused on the rapidly expanding field of fluorescent polymeric materials due to their intriguing structure as well as their potential applications as functional materials in many areas such as electroluminescent devices, ${ }^{1,2}$ chemosensors, ${ }^{3-5}$ biological detection, ${ }^{6,7}$ nuclear detection, ${ }^{8} \mathrm{pH}$ sensing, ${ }^{9}$ and so on. ${ }^{10,11}$ In the last decade, fluorescent polymeric materials have been widely studied, owing to their promising applications, and so far, many kinds of fluorescent polymeric materials have been generated. In general, there are two main approaches to preparation of fluorescent polymeric materials. One is including dye-doped polymer ${ }^{8,12-14}$ or quantum dots (QDs) $)^{15-17}$ embedded in polymer. However, the dye leakage from polymer in the dye-doped polymeric materials is still a problem whichever kind of dye is used. Furthermore, the application of QDs has been limited by their unbiocompatibility because of their poor solubility in water unless they are modified and agglutination as optical probes. The other one is polymerization of a functional monomer ${ }^{18,19}$ which contains fluorescent chromophores or groups of whichever kind (organic or inorganic). Although it is cumbersome to synthesize and purify a new fluorescent monomer, this method could decrease the leakage and resolve the problem of incompatibility in deed to a certain extent.
In recent years, there has been a growing interest in the fluorescent properties of rare earth metal containing polymers because this kind of functional materials not only has the unique properties of rare earth ion such as fluorescent, electric, and magnetic but also has the special properties of polymer, such as light weight, high impaction, and easy process. There are two types of fluorescent polymer, one is doped type $e^{20,21}$ and the other is bond type. ${ }^{22-24}$ The performance and application of the doped type polymer is restricted because the rare earth ion is not well dispersed in the polymer. Nevertheless, the bond type polymer can enhance the appetency force of rare earth compounds, raise transparency and mechanical performance of material.

It is well known that deoxyribonucleic acid (DNA) is an important genetic substance in organism which plays important roles in life process. Errors in gene expression can often cause disease and play a secondary role in the outcome and severity of human disease. Research on the interaction between molecules and DNA is of great importance for finding novel and potential biomaterials for both clinical and laboratory tests. ${ }^{25-27}$ Although, many kinds of fluorescent polymer containing rare earth ions for various applications have been synthesized and characterized, ${ }^{28-31}$ the report of preparation, characterization of water soluble fluorescent polymer 
containing rare earth complex, and its interaction with biomacromolecules such as DNA is rare. Thus, the study on this should be remarkably desired. Herein, our work focuses on the preparation of the fluorescent polymer and its interaction with DNA.

In this article, we synthesized and characterized a complex containing high polymerization activity and intense fluorescent properties with europium ion, in conjugated with acrylic acid (AA) and the neutral ligand 1,10-phenanthroline (Phen). In the following steps, highly fluorescent Eu-containing polymer (PPNEU) was synthesized through the copolymerization of the complex monomer with other functional monomers. Then, preliminary studies on the interaction of fluorescent polymer containing rare earth complex with DNA were carried on. Its ability on DNA complexation was investigated in order to assess potential application in gene determination and gene delivery.

\section{EXPERIMENTAL}

\section{Materials}

Europium oxide $\left(\mathrm{Eu}_{2} \mathrm{O}_{3}, 99.99\right.$ wt \%) was purchased from Shanghai Yuelong Nonferrous Metals and used without further purification. $N$-isopropylarylamide (NIPAm, 99\%) was obtained from Acros Organics and used as received. Poly (ethylene glycol) methyl ether methacrylate (PEGMA, $M_{\mathrm{n}}=$ 1100) was supplied by Aldrich. Calf thymus DNA (ct-DNA) was supplied by Beijing Shuangxuan Biological Culture Medium Plant (Beijing, China). The stock solution of $c t-D N A$ was prepared by dissolving $c t-D N A$ in distilled water at $0-4{ }^{\circ} \mathrm{C}$. The concentration of $c t$-DNA working solution was $42 \mathrm{mg} / \mathrm{L}$. Plasmid DNA (2.68 Kb), loading buffer and other biochemicals were supplied by the group of Prof. Ma (Faculty of Biology Science, Hubei University). Azodiisobutyronitrile (AIBN, analytical grade) used as initiator was recrystallized twice from ethanol and stored in refrigerator before use. AA (analytical grade) was purified before use. Hydrochloric acid $(\mathrm{HCl})$, tetrahydrofuran (THF), hexane, methanol, 1,10-phenanthroline (Phen), ammonia $\left(\mathrm{NH}_{3} \cdot \mathrm{H}_{2} \mathrm{O}\right)$, absolute ethanol (95\%), and other chemicals were all analytical grade and used without further purification.

\section{Measurement Techniques}

Fourier transform infrared (FTIR) spectra were performed on the PerkinElmer Spectrum one Transform Infrared spectrometer (PerkinElmer). The FTIR spectra were recorded from 4000 to $400 \mathrm{~cm}^{-1}$. Nuclear Magnetic Resonance $\left({ }^{1} \mathrm{H}\right.$ NMR) spectra were recorded on a UNITY INVOA-600 $\mathrm{MHz}$ spectrometer (Varian) at $20{ }^{\circ} \mathrm{C}$ with $\mathrm{DMSO}-d_{6}$ and $\mathrm{CDCl}_{3}$ as the solvent. The contents of carbon, hydrogen, and nitrogen were determined with an Elementary Vario ELIII elemental analyzer (Germany) and the content of $\mathrm{Eu}^{3+}$ was determined by ethylenediaminetetraacetic acid (EDTA) titration. Absorption spectra were recorded with a Varian Cary UV-500 spectrophotometer. Excitation and emission fluorescent spectra were measured on a RF-540 spectrometer (Hitachi HighTechnologies Corporation, Tokyo, Japan). The molecular weight and molecular weight distribution were determined by a Waters $150-\mathrm{C}$ gel permeation chromatograph (GPC) at
$30{ }^{\circ} \mathrm{C}$. THF was used as the eluent at a flow rate of $1.0 \mathrm{~mL}$ $\min ^{-1}$. The morphology of the fluorescent polymer and the morphology of the interaction of the polymer with ct DNA were characterized by TEM (Tecnai G20, FEI Corp.). The sample was not stained and a drop of the sample was placed on a Formvar-coated copper grid which was dried in air. The TEM images were obtained at $25{ }^{\circ} \mathrm{C}$ at an electron acceleration voltage of $200 \mathrm{kV}$.

\section{Synthesis of Eu(AA) ${ }_{3}$ Phen Complex Monomer}

A calculated weight of $\mathrm{Eu}_{2} \mathrm{O}_{3}$ was dissolved in excess concentrated $\mathrm{HCl}$ and evaporated to near dryness, and then ethanol was added to the crystal and the solution of $\mathrm{EuCl}_{3}$ in ethanol (0.1 mol L ${ }^{-1}$ ) was obtained. AA (12 mmol) and Phen ( $4 \mathrm{mmol}$ ) were dissolved in a $40 \mathrm{~mL} \mathrm{95 \%} \mathrm{ethanol.} \mathrm{Then} 40$ $\mathrm{mL}$ of an $\mathrm{EuCl}_{3}$ solution ( $4 \mathrm{mmol}$ ) was slowly dropped into the previous solution with constant stirring. The $\mathrm{pH}$ value of the mixture solution was adjusted to $\mathrm{pH}$ 7-8 with $\mathrm{NH}_{3}$. $\mathrm{H}_{2} \mathrm{O}$, and the mixture was stirred at $65^{\circ} \mathrm{C}$ for $12 \mathrm{~h}$, then precipitated, filtered, washed repeatedly with ethanol, and dried in vacuum at $50{ }^{\circ} \mathrm{C}$ for $6 \mathrm{~h}$.

Synthesis of PEGMA-co-NIPAm-co-Eu(AA) $)_{3}$ Phen (PPNEu) The copolymerization of $\operatorname{Eu}(\mathrm{AA})_{3}$ Phen with PEGMA and NIPAm was carried out in a methanol solution. The typical amount of AIBN, Eu(AA) $)_{3}$ Phen, PEGMA and NIPAm in the feed was $0.014,0.2,0.5$, and $1.5 \mathrm{~g}$, respectively. The methanol solution was $40 \mathrm{~mL}$. Under such conditions, essentially homogeneous copolymerization occurred. The procedure can be describe as follows: $\mathrm{Eu}(\mathrm{AA})_{3}$ Phen was dissolved in $40 \mathrm{~mL}$ methanol solution and mixed with PEGMA and NIPAm, and then the homogeneous solution was placed in a round bottom flask equipped with a water cooled reflux condenser, a Teflon stirrer, thermal meter for monitoring the temperature and a nitrogen bleed. The air in the flask was replaced by a stream of nitrogen. Then, the system was placed in water bath and when it got to $63{ }^{\circ} \mathrm{C}$, AIBN was injected into the flask. The polymerization procedure lasted for $20 \mathrm{~h}$ and the system was kept under nitrogen atmosphere until polymerization finished. The viscous and homogeneous solution was obtained and the solvent was evaporated under reduced pressure. After that treatment, the wild product was then dissolved in THF, filtered, purified by reprecipitation of solution with hexane for three times, and dried in vacuum for 1 day. PEGMA-Co-NIPAm (PPN) was synthesized and purified under the same condition as $P P N E u$.

\section{Agarose Gels Electrophoresis}

Polymer/plasmid complexes were prepared freshly prior to use. Polymer solution and the pure plasmid DNA solutions had concentrations of $1 \mathrm{mg} \mathrm{mL}^{-1}$ and $0.1 \mu \mathrm{g} \mu \mathrm{L}^{-1}$, respectively, in ultrapure water. The plasmid DNA solutions were then added to the polymer solutions in different ration (w/w) and complexation was allowed for $30 \mathrm{~min}$ at $37{ }^{\circ} \mathrm{C}$ before using.

To assay the ability of polymer to retard the movement of plasmid DNA in the agarose gel, the mixture of polymer/ plasmid DNA complexes aqueous solution and loading buffer were loaded on to a $1.2 \%$ agarose gel and run for $0.5 \mathrm{~h}$ at 


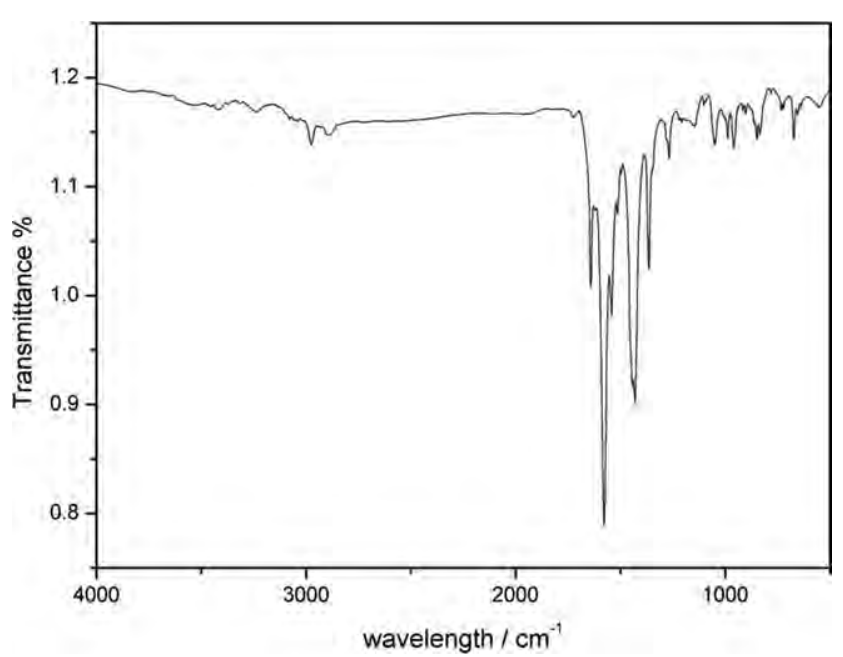

FIGURE 1 FTIR spectrum of Eu complex.

120 constant volts using JM-250 unit (China). The gels were then scanned by a Gene Genius Bioimaging system.

\section{RESULTS AND DISCUSSION}

\section{Characterization of the Eu Complex and PPNEu}

The $\mathrm{C}, \mathrm{H}$, and $\mathrm{N}$ contents of the complex, determined by elemental analysis, were as follows: C, 45.61\%; H, 3.024\%; N, $5.138 \%$. The Eu content, determined by EDTA titration, was $27.98 \%$. The theoretical calculated values for the complex were as follows: C, 46.23\%; H, 3.12\%; N, 5.14\%, Eu, $27.89 \%$. The FT-IR spectrum of the complex was shown in Figure 1. The stretching vibration of $\mathrm{C}=\mathrm{N}$ Phen at $1650 \mathrm{~cm}^{-1}$ and the bent vibration at 854 and $739 \mathrm{~cm}^{-1}$ were shifted to lower frequency at 1642,849 , and $732 \mathrm{~cm}^{-1}$, respectively, which indicated that Phen had coordinated with the Eu ion. The $\mathrm{C}=0$ stretching bands of free $\mathrm{AA}$ at $1724 \mathrm{~cm}^{-1}$ were essentially absent in the complex. The strong bands at 1542 and $1430 \mathrm{~cm}^{-1}$ corresponded to the antisymmetric and symmetric stretching vibrations of $\mathrm{COO}^{-1}$ confirmed that $\mathrm{AA}$ had

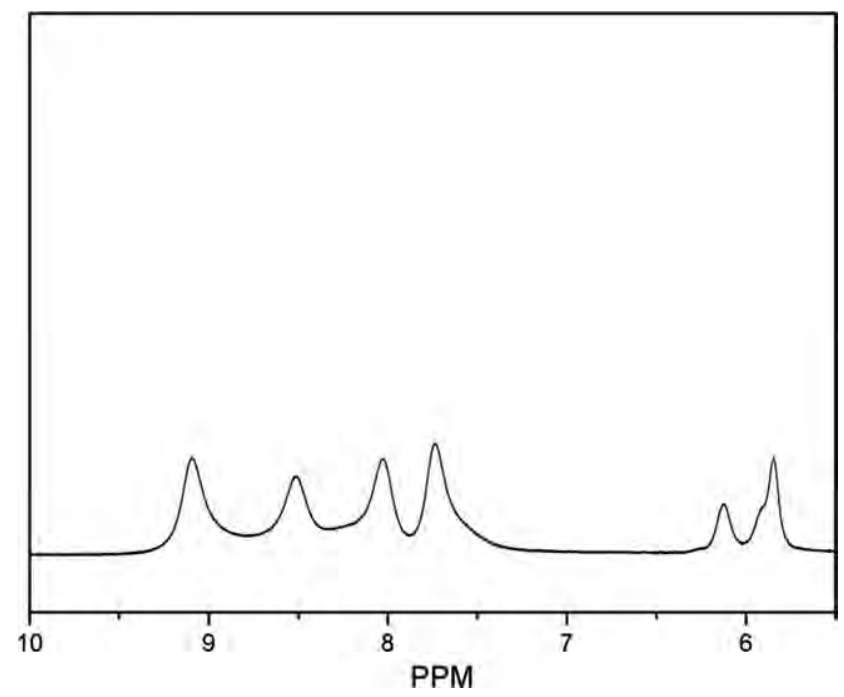

FIGURE $2{ }^{1} \mathrm{H}$ NMR spectrum of Eu complex. coordinated with the $\mathrm{Eu}$ ion. The absence of absorption bands in the region of $3200-3500 \mathrm{~cm}^{-1}$ indicated that there was no coordinated water or hydroxyl group in the complex. Figure 2 showed the $600 \mathrm{MHz}{ }^{1} \mathrm{H}$ NMR spectrum of Eu complex (in DMSO- $d_{6}$ ). The resonances for Phen protons occurred at 7.78-9.11 ppm, and the peaks around $6.0 \mathrm{ppm}$ attributed to the protons of $\mathrm{H}_{2} \mathrm{C}=\mathrm{CH}-$ of AA. These experimental results suggested that a reasonable formula for the complex was $\mathrm{Eu}(\mathrm{AA})_{3}$ Phen.

Figure $3(a, b)$ showed the excitation and emission spectra of $\mathrm{Eu}(\mathrm{AA})_{3}$ Phen monomer. The excitation spectrum of Eu(AA) $)_{3-}$ Phen was obtained by monitoring emission intensity of $\mathrm{Eu}^{3+}$ at $618 \mathrm{~nm}$. The maximum absorption of the Eu(AA) $)_{3}$ Phen occurred within the range of 325-375 $\mathrm{nm}$ and dominated by peak centered at $350 \mathrm{~nm}$, which may be resulted from conjugating $\pi-\pi^{*}$ transitions of Phen. As a result, the emission lines of the $\mathrm{Eu}(\mathrm{AA})_{3}$ Phen were obtained from the ${ }^{5} \mathrm{D}_{0}{ }^{-}{ }^{7} \mathrm{~F}_{\mathrm{n}}$ $(n=1-3)$ transitions at 594, 618, $645 \mathrm{~nm}$ for europium ions under the excitation wavelength at $350 \mathrm{~nm}$. Among these bands, the emission at $618 \mathrm{~nm}$ due to the ${ }^{5} \mathrm{D}_{0^{-}}{ }^{7} \mathrm{~F}_{2}$ electrodipolar transition was the strongest, indicating low symmetry environment around the $\mathrm{Eu}^{3+}$ ion in the $\mathrm{Eu}(\mathrm{AA})_{3}$ Phen. ${ }^{32}$
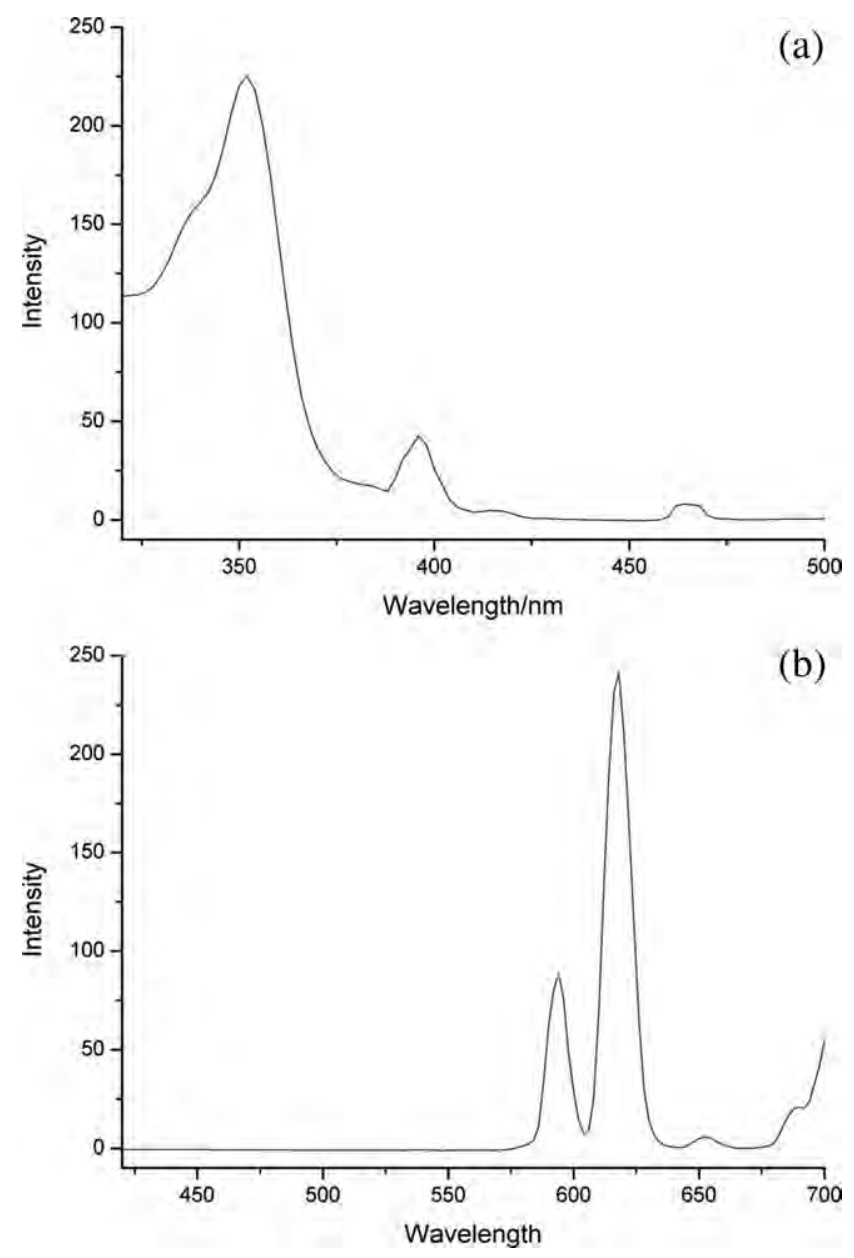

FIGURE 3 Excitation and Emission spectra of Eu(AA) $)_{3}$ Phen. (a) Excitation $\lambda_{\mathrm{em}}=618 \mathrm{~nm}$, (b) Emission $\lambda_{\mathrm{es}}=350 \mathrm{~nm}$. 


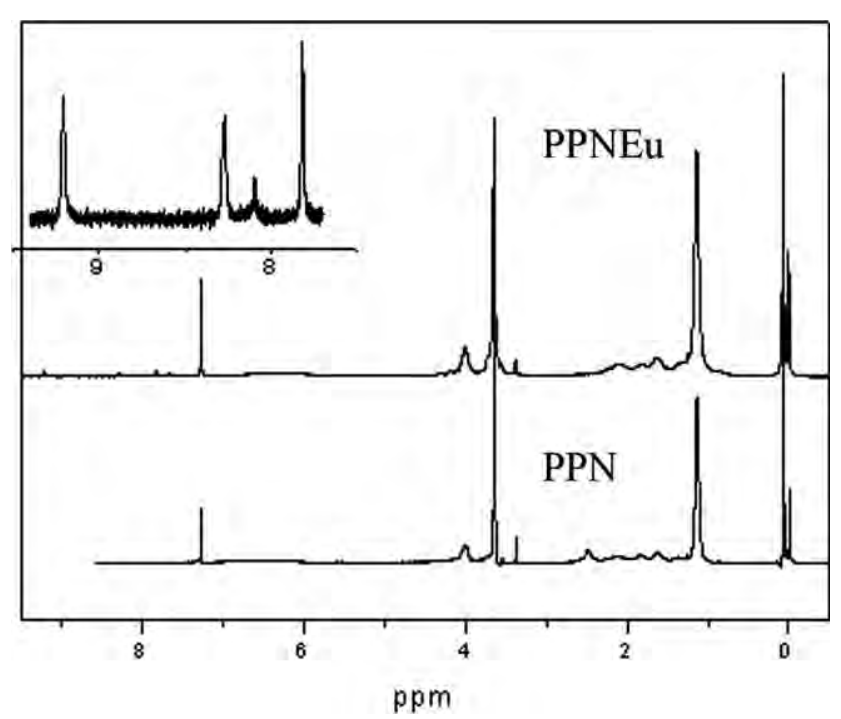

FIGURE $4{ }^{1} \mathrm{H}$ NMR spectra of PPNEU and PPN.

The most striking red luminescence $\left({ }^{5} \mathrm{D}_{0}-{ }^{7} \mathrm{~F}_{2}\right)$ was observed in this emission spectra which indicated that the effective energy transfer took place between ligands and the chelated europium ions. $^{33}$ Thus, the $\mathrm{Eu}(\mathrm{AA})_{3}$ Phen is with great monochromaticity.

The ${ }^{1} \mathrm{H}$ NMR spectra of PPNEu and PPN measured in $\mathrm{CDCl}_{3}$ were presented in Figure 4. As shown in Figure 5, the ${ }^{1} \mathrm{H}$ NMR spectra of two polymers were nearly the same, where the resonances for protons of $-\mathrm{CH}_{2} \mathrm{CH}_{2}-\mathrm{O}-$ group in PEG side chains occur at $3.65 \mathrm{ppm}$, and the peaks around 1.25 and $4.01 \mathrm{ppm}$ attributed to the protons of $-\mathrm{CH}_{3}$ and $-\mathrm{CH}-$ on isopropyl separately. In the spectrum of $P P N$, there were no visible resonance peaks after $7.8 \mathrm{ppm}$. However, in the spectrum of $P P N E u$, there occurred resonance peaks in the region of 7.8-9.2 ppm in contrast, which was in agreement with the results in Figure 2. The ${ }^{1} \mathrm{H}$ NMR results indicated

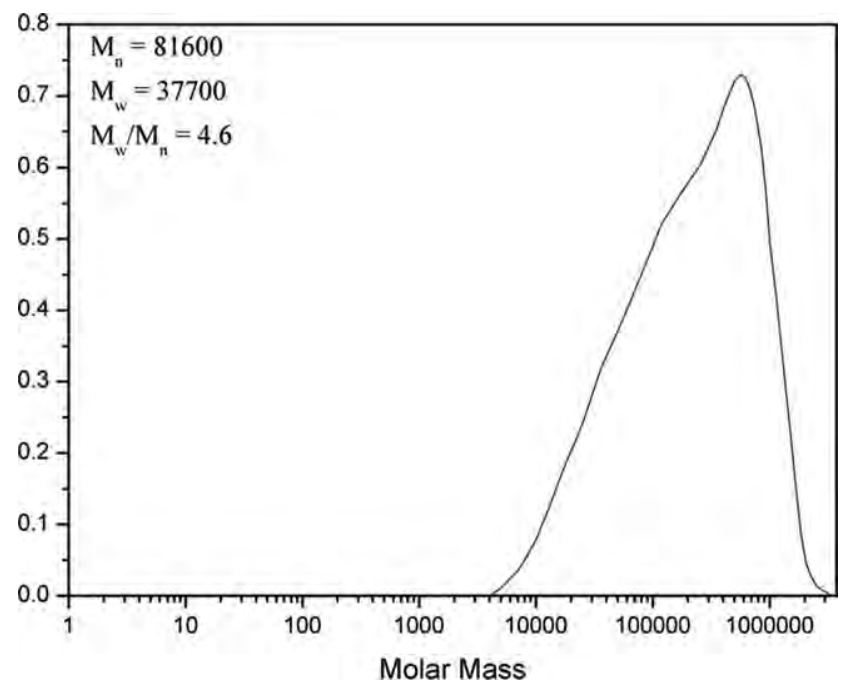

FIGURE 5 Typical GPC curve of PPNEu. $M_{\mathrm{n}}=81,600$ and $M_{\mathrm{w}}=$ 377,600 . that copolymerization of $\mathrm{Eu}$ complex monomer and functional monomer was successfully carried out.

The molecular weight and molecular weight distribution of $P P N E u$ were determined by GPC. Chromatogram recorded from the $P P N E u$ was shown in Figure 5. This chromatogram of typical $P P N E$ indicated a unimodal molecular weight, the polymerization was successfully carried out and high-molecular weight copolymer was obtained.

\section{Fluorescent Properties of PPNEu}

Figure 6 showed the emission spectra of $P P N E U$ and PPN in water solution $\left(0.05 \mathrm{~g} \mathrm{~L}^{-1}\right)$. The emission was excited at $350 \mathrm{~nm}$. The PPNEU and PPN both had the broad emission centered at $368 \mathrm{~nm}$, however the intensity of the emission peak of PPNEU was stronger than that of PPN. The broad emission peak at $368 \mathrm{~nm}$ was due to singlet $\mathrm{S}_{0} \rightarrow \mathrm{S}_{1}$ transition of the polymer backbone. Furthermore, the PPNEu had the characteristic emission peak of europium ions at 594 and $618 \mathrm{~nm}$, which were in accordance with the result in Figure 3(B). This fluorescence result showed the energy transfer process initially from the ligand and the polymer singlet state $S_{1}$, finally to the europium ions was efficient.

\section{Absorption Spectra of the Interaction of the PPNEu and ct DNA}

Absorption spectroscopy is universally employed to determine the binding characteristics of molecules with DNA. ${ }^{34}$ Intercalative mode, static electronic mode and groove binding mode were well known as the interaction modes of molecules with DNA. ${ }^{35}$ The interaction mode of molecules with DNA usually has been characterized by large changes in the absorbance (hypochromicity) and appreciable shift in wavelength (red shift). ${ }^{36-38}$ When molecules bind to DNA in an intercalation way, the intensity of their absorption will

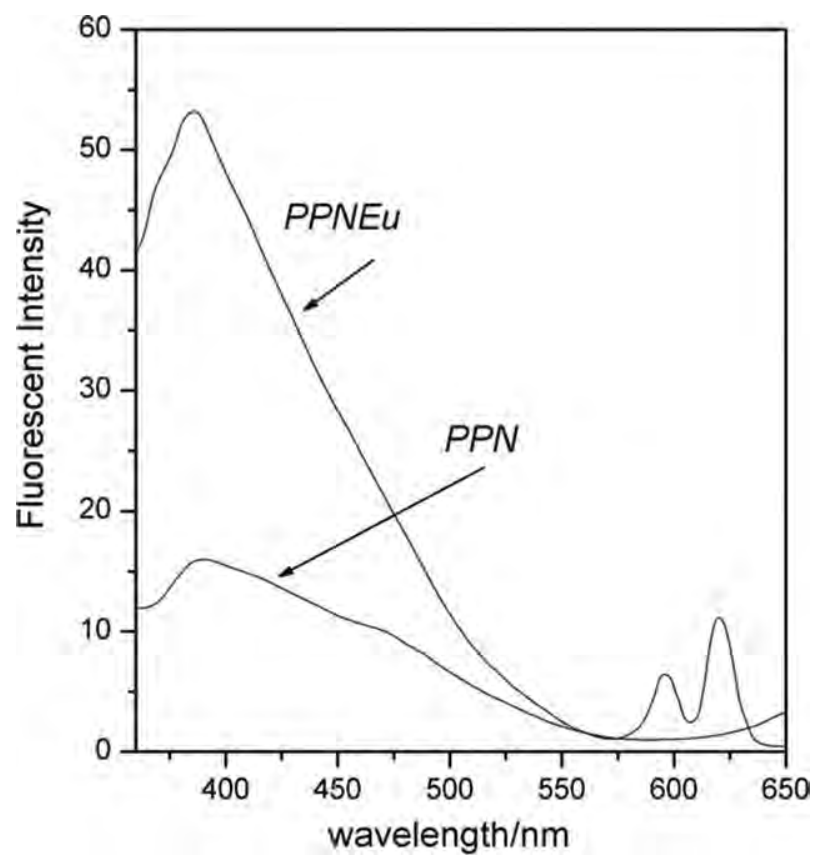

FIGURE 6 Fluorescent emission spectra of PPNEu and PPN. 


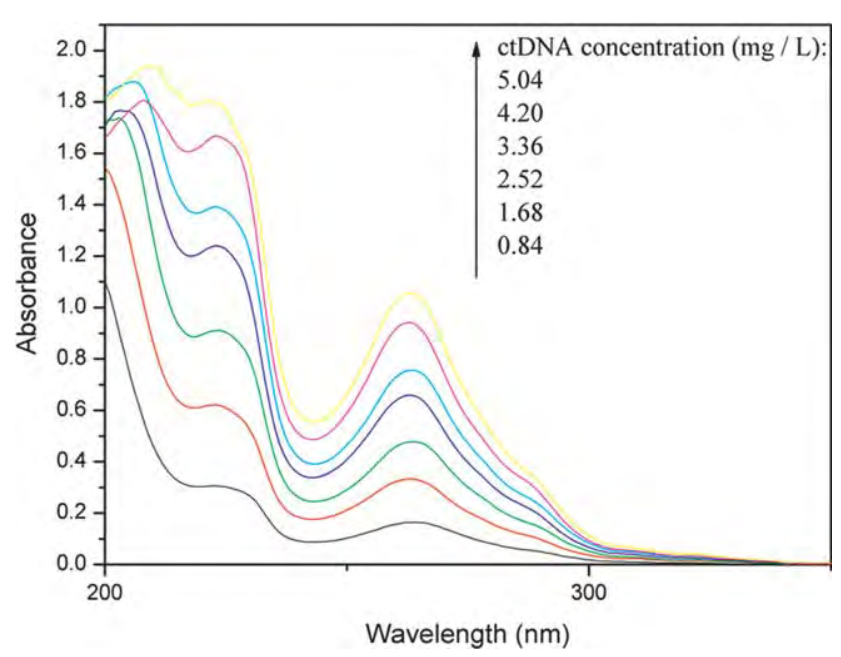

FIGURE 7 UV spectra of the PPNEu at different concentration of ct DNA. Polymer concentration: $0.25 \mathrm{~g} \mathrm{~L}^{-1}$.

decrease and the absorption will shift to longer wavelength. But, molecules which bind nonintercalatively or electrostatically with DNA may result in hyperchromism. ${ }^{39,40}$

To investigate the mode of the PPNEU binding to DNA, absorption titration experiment has been carried out. When adding $c t-D N A$ to the solution of the PPNEu, a considerable increase in absorption was observed in Figure 7. In Figure 7, the hyperchromicity effect showed that PPNEu could bind to ct $D N A$, which might due to the static electronic interaction between PPNEU and ct DNA.

\section{Fluorescence Spectrum of the Interaction of PPNEu with ct DNA}

Figure 8 showed the fluorescent emission spectra of $P P N E U$ in the presence of varying amounts of ct DNA. As seen from Figure 8, the intensity of emission at 594 and $618 \mathrm{~nm}$ increased dramatically in the presence of $c t$ DNA. The enhancements of emission intensity implied that the $P P N E U$ and ct DNA complexation was formed by electrostatic interaction between negatively charged phosphate groups of the ct DNA and the positively charged groups $\left(\mathrm{Eu}^{3+}\right.$ containing groups) of $P P N E u$. As a result of the complexation effect, these groups $\left(\mathrm{Eu}^{3+}\right.$ containing groups) of PPNEu were protected from solvent water molecules by the hydrophobic environment supplied by the DNA helix; the accessibility of solvent water molecules to $P P N E u$ was reduced, which usually led to the fluorescence emission enhancement.

\section{TEM images of Complexes of PPNEu and ct DNA}

To appreciate the interaction between PPNEu and ct DNA further, the TEM images of PPNEu $\left(0.25 \mathrm{~g} \mathrm{~L}^{-1}\right)$, pure $c t D N A$ (5.04 $\mathrm{mg} \mathrm{L}^{-1}$ ) and their complexes were provided in Figure 9. Figure $9(\mathrm{~A})$ showed that the $P P N E u$ formed spherical micelles in the aqueous solution and the spherical micelles were smaller than $100 \mathrm{~nm}$ in diameter. As shown in Figure 9(B), ct DNA displayed a relaxed, open-loop structure with little twisting of the strands.
Figure $9(\mathrm{C}, \mathrm{D})$ showed the TEM images of PPNEU $(0.25 \mathrm{~g}$ $\mathrm{L}^{-1}$ )/ct DNA at different $c t$ DNA concentration (C, $0.84 \mathrm{mg}$ $\mathrm{L}^{-1} ; \mathrm{D}, 5.04 \mathrm{mg} \mathrm{L}^{-1}$ ). At low concentration of $c t$ DNA in Figure $9(\mathrm{C})$, because of the interaction between $P P N E u$ and ct DNA, the aggregation of $P P N E u$ and ct DNA were observed. In comparison with Figure 9(A), the morphology and size of the micelles change significantly. It is interesting that in Figure $9(\mathrm{C})$, when ct DNA was added into PPNEu solution, the aggregation phenomenon occurred, the size of micelles became smaller and the micelles deformed. This may be due to the collapse of the micelles after the interaction and aggregation. Furthermore, at low ct DNA concentration, the dissociative ct DNA was not obviously observed as shown in Figure $9(\mathrm{C})$ and nearly all complexes displayed roughly spherical shape, which verified the impression of efficient complexation. At the high ct DNA concentration as shown in Figure 9(D), ct DNA was only partially complexed by polymer, therefore, the dissociative coiled chains of ct DNA were still observed in Figure 9(D). The discretely spheres with larger size in image implied that at high ct DNA concentration, the aggregation began to disappear and larger spheres formed. As an efficient gene carrier, synthetic polymer should be able to interact with DNA and form polymer/DNA complexes small enough to enter a cell through endocytosis. This size requirement is on the order of $200 \mathrm{~nm}$ or less for most cell types. ${ }^{41}$ In this study, the average diameters of complexes as shown in Figure 9 fall in the general size requirements for cellular endocytosis.

\section{Complexation of Polymer and Plasmid DNA}

Physical integrity of the DNA after complexation is a prerequisite for biological activity of the DNA to mediate successful transition. A fixed amount of plasmid DNA $\left(\begin{array}{lll}0.5 & \mu \mathrm{g}\end{array}\right)$

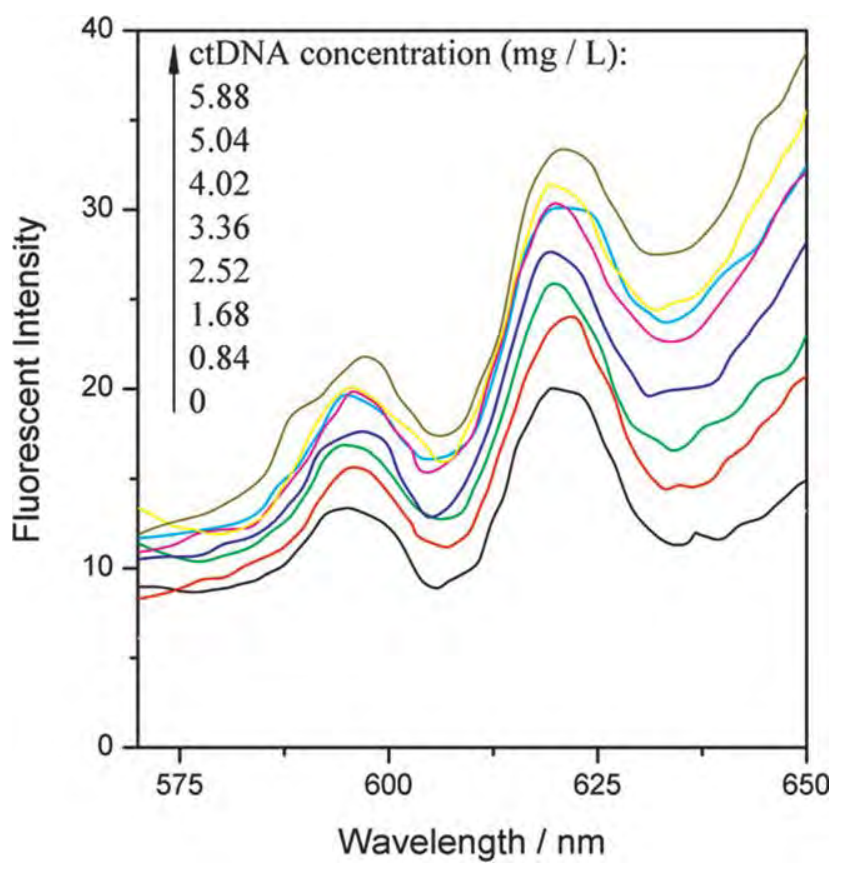

FIGURE 8 Fluorescent spectra of PPNEu at different ct DNA concentration. Polymer concentration: $0.25 \mathrm{~g} \mathrm{~L}^{-1}$. 

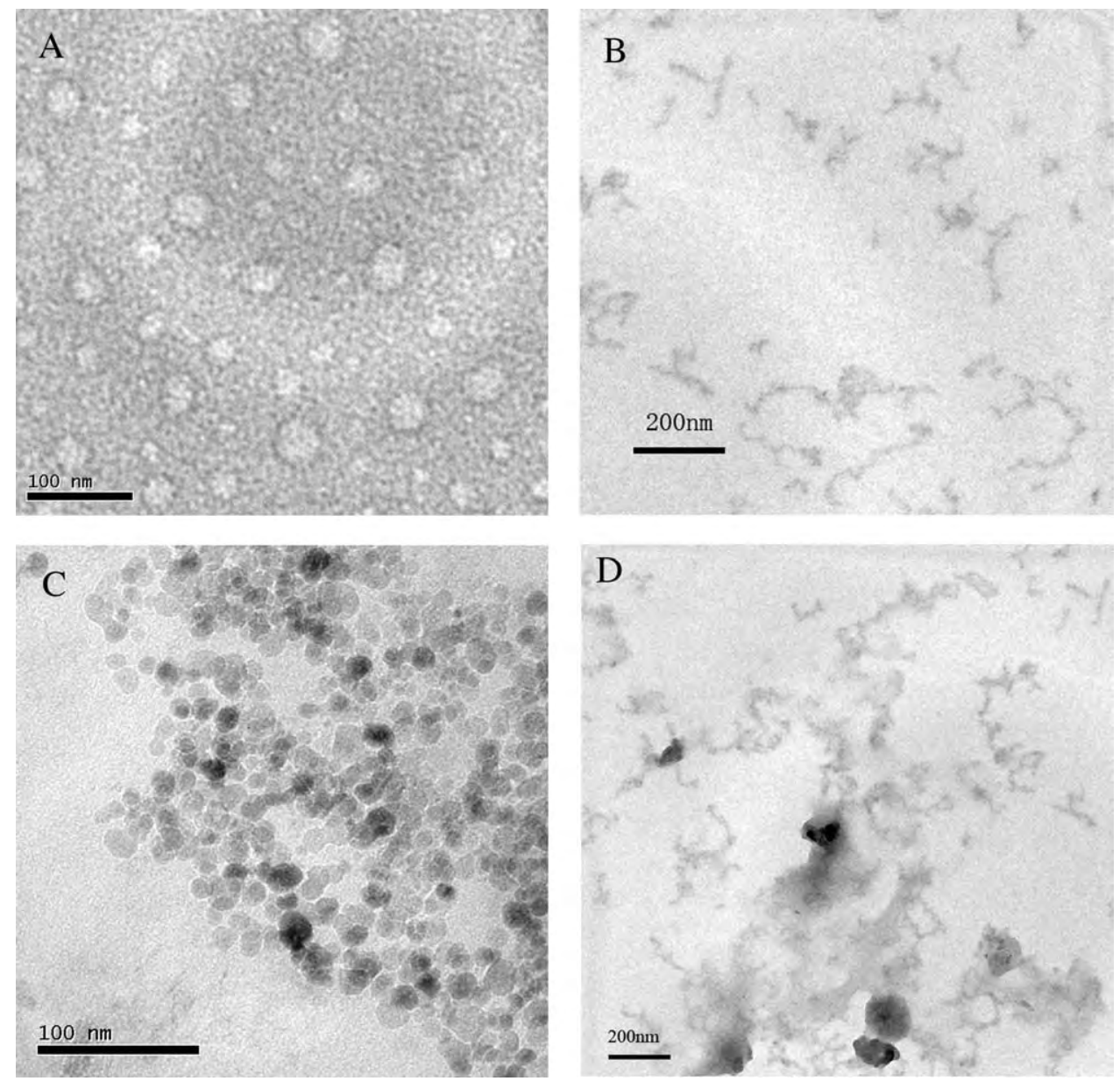

FIGURE $9 \mathrm{~A}$ and $\mathrm{B}$ are the TEM images of PPNEu $\left(0.25 \mathrm{~g} \mathrm{~L}^{-1}\right)$ and pure ct DNA (42 $\left.\mathrm{mg} \mathrm{L}^{-1}\right)$, respectively. $C$ and $D$ are the TEM images of PPNEulct DNA complex micelles at different $c t$ DNA concentration (C: $1.68 \mathrm{mg}$ $\mathrm{L}^{-1}$, D: $5.04 \mathrm{mg} \mathrm{L}^{-1}$ ). complexed with $P P N E u$ aqueous solutions $\left(2.5 \mathrm{mg} \mathrm{mL}^{-1}\right)$ at various ratios was investigated by using DNA mobility retardation assays on agarose gels via electrophoresis and the results were shown in Figure 10. Loading of plasmid DNA was varied by complexing different amount of the PPNEU

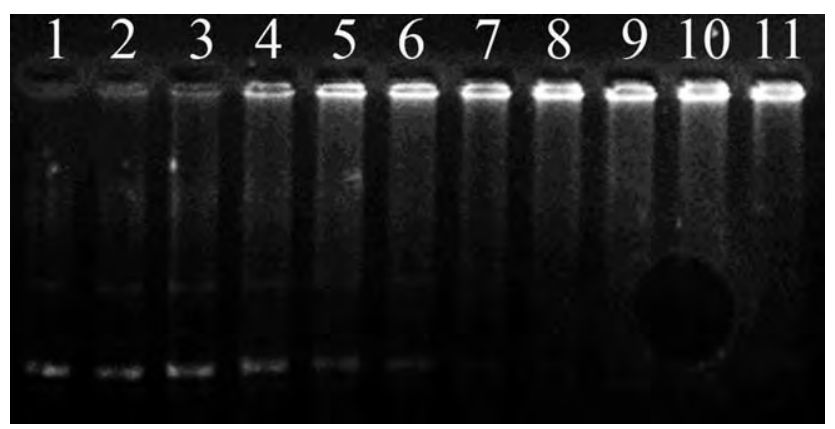

FIGURE 10 Complexation of plasmid DNA and Polymer. Agarose electrophoretic mobility retardation assays were carried out at 120 constant volts. Electrophoresis picture were taken under a Gene Genius Bioimaging system. Lane 1: pure plasmid DNA (0.5 $\mu \mathrm{g})$. Lane 2, 3, 4, 5, 6, 7, 8, 9, 10, and 11: $0.5 \mu \mathrm{g}$ plasmid DNA complexed with 2.5, 5,7.5, 10, 12.5, 15, 20, 25, 30, and $40 \mu \mathrm{g}$ of polymer, respectively. with standard amount of the plasmid DNA at weight rations of $5 / 1,10 / 1,15 / 1,20 / 1,25 / 1,30 / 1,40 / 1,50 / 1,60 / 1$, and $80 / 1$. Plasmid DNA was partially retained in the presence of PPNEu/plasmid DNA at mass ratio of 5/1 (lane 2), 10/1 (lane 3), 15/1 (lane 4), 20/1 (lane 5), 25/1 (lane 6) and totally retained at mass ratio of 30/1 (lane 7), 40/1 (lane 8), 50/1 (lane 9), 60/1 (lane 10), and 80/1 (lane 11). This result indicated that all the plasmid DNA complexed with polymer. In these systems, self-assembling complexes of plasmid DNA and polymer were formed as a result of electrostatic interactions between the negatively charged phosphate groups of the plasmid DNA and the positively charged groups of PPNEU.

\section{CONCLUSIONS}

Water-soluble fluorescent copolymer PPNEU was successfully synthesized by free radical copolymerization in methanol with AIBN as initiator. The structure and fluorescent property were characterized. The results of fluorescence, UV-vis absorption, and agarose electrophoresis indicated that the $P P N E u$ could interact with DNA in an electrostatic bonding mode. The TEM observation showed that the PPNEU could form spherical micelles in water solution small than $100 \mathrm{~nm}$; the efficient complexation of PPNEu with DNA occurred. 
These results suggested the potential of the PPNEu as gene detective reagent and gene delivery carrier.

This work is supported by the National Natural Science Foundation of China (No. 50973027) and Specialized Research Fund for the Doctoral Program of Higher Education (No. 20094208110002). The authors are grateful to Gongwu Song and his group, Faculty of Chemistry and Chemical Engineering, for their help in fluorescence spectra determination; Lixin Ma and his group, Faculty of Biology Science, for their help in DNA complexation determination, respectively.

\section{REFERENCES AND NOTES}

1 Zhang, J.; Xie, Y. R.; Ye, Q.; Xiong, R. G.; Xue, Z.; You, X. Z. Eur J Inorg Chem 2003, 2003, 2572-2577.

2 Li, L.; Xu, C.; Li, S. Macromol Chem Phys 2009, 210, 1097-1103.

3 Miao, Q.; Huang, X.; Cheng, Y.; Liu, Y.; Zong, L.; Cheng, Y. J Appl Polym Sci 111, 2009, 3137-3143.

4 Zhu, M.; Zhou, C.; Zhao, Y.; Li, Y.; Liu, H.; Li, Y. Macromol Rapid Commun 2009, 30, 1339-1344.

5 Fernando, N.; Javier, L.; Urraca, M. C.; Guillermo, O. Sens Actuators B 2007, 121, 67-73.

6 Hun, X.; Zhang, Z.; Tiao, L. Anal Chim Acta 2008, 625, 201-206.

7 Yang, X.; Zhao, X.; Zuo, X.; Wang, K.; Wen, J.; Zhang, H. Talanta 2009, 77, 1027-1031.

8 Hamel, M.; Simic, V.; Normand, S. React Funct Polym 2008, 68, 1671-1681.

9 Allard, E.; Larpent, C. J Polym Sci Part A: Polym Chem 2008, 46, 6206-6213.

$10 \mathrm{Hu}$, Y.; Wang, B.; Su, Z. Polym Int 2008, 57, 1343-1350.

11 Huang, H.; Wang, K.; Tan, W.; An, D.; Yang, X.; Huang, S.; Zhai, Q.; Zhou, L.; Jin, Y. Angew Chem 2004, 116, 5753-5756.

12 Baharvand, H. J Appl Polym Sci 2008, 109, 1823-1828.

13 Kan, S.; Liu, X.; Shen, F.; Zhang, J.; Ma, Y.; Zhang, G.; Wang, Y.; Shen, J. Adv Funct Mater 2003, 13, 603-608.

14 Tamai, T.; Watanbe, M.; Maeda, H.; Mizuno, K. J Polym Sci Part A: Polym Chem 2008, 46, 1470-1475.

15 Li, M.; Zhang, H.; Zhang, J.; Wang, C.; Han, K.; Yang, B. J Colloid Interface Sci 2006, 300, 564-568.

16 Zhang, H.; Cui, Z.; Wang, Y.; Zhang, K.; Ji, X.; Lu, C.; Yang, B.; Gao, Y. Adv Mater 2003, 15, 777-710.

17 Zhang, H.; Wang, C.; Li, M.; Zhang, J.; Lu, G.; Yang, B. Adv Mater 2005, 17, 853-857.

18 Campo, L. F.; Rodembusch, F. S.; Stefani, V. J Appl Polym Sci 2006, 99, 2109-2116.
19 Chiellini, E.; Solaro, R.; Ciardelli, F.; Galli, G.; Ledwith, A. Polym Bull 1980, 2, 577-587.

20 Nakajima, H.; Kawano, K. J Alloys Compd 2006, 7, 408-412.

21 Hilder, M.; Junk, P. C.; Lezhnina, M. M.; Warzala, M.; Kynast, U. H. J Alloys Compd 2008, 451, 530-533.

22 Liu, X.; Hu, Y.; Wang, B.; Su, Z. Synth Met 2009, 159, 1557-1562.

23 Du, C.; Ma, L.; Xu, Y.; Li, W. J Appl Polym Sci 1997, 66, 1405-1410.

24 Pan, Y.; Zheng, A.; Hu, F.; Xiao, H. J Appl Polym Sci 2006, 100, 1506-1510.

25 Li, T.; Yang, Z.; Wang, B.; Qin, D. J Med Chem 2008, 43, 1688-1695.

26 Wu, M.; Wu, W.; Gao, X.; Lin, X.; Xie, Z. Talanta 2008, 75, 995-1001.

27 Qiu, B.; Guo, L.; Wang, W.; Chen, G. Biosens Bioelectron 2007, 22, 2629-2635.

28 Liu, X.; Hu, Y.; Wang, B.; Su, Z. Synth Met 2009, 159, 1557-1561.

29 Yan, B.; Wang, Q. J Photochem Photobiol A Chem 2008, 197, 213-221.

30 Wang, Q.; Yan, B. J Photochem Photobiol A Chem 2006, $177,1-5$.

$31 \mathrm{Xu}$, J.; Huang, X. H.; Zhou, N. L.; Zhang, J. S.; Bao, J. C.; Lu, T. H.; Li, C. Mater Lett 2004, 58, 1938-1944.

32 Hasegawa, Y.; Yamamuro, M.; Wada, Y.; Kanehisa, N.; Kai, Y.; Yanagida, S. J Phys Chem A 2003, 107, 1697-1702.

33 Dias, B.; Viswanathan, S. Chem Commun 2004, 8, 10241025.

34 Li, H.; Le, X. Y.; Pang, D. W.; Deng, H.; Xu, Z. H.; Lin, Z. H. J Inorg Biochem 2005, 99, 2240-2247.

35 Micheson, A. M. The Chemistry of Nucleosides and Nucleotides; Academic Press: London and New York, 1993; pp 7883.

36 Liu, J.; Zhang, T. X.; Lu, T. B.; Qu, L. H.; Zhou, H.; Zhang, Q. L.; Ji, L. N. J Inorg Biochem 2002, 91, 269-276.

37 Sastri, C. V.; Eswaramoorthy, D.; Giribabu, L. J Inorg Biochem 2003, 94, 138-145.

38 Shen, T.; Wang, J. Y. Biochemisty; High Education Press: Beijing, 1990; pp. 105-107.

39 Barton, K.; Danishefsky, A. T.; Goldberg, J. M. J Am Chem Soc 1984, 106, 2172-2176.

40 Lawrence, D.; Vaidyanathan, V. G.; Nair, B. U. J Inorg Biochem 2006, 100, 1244-1251.

41 Zauner, W.; Ogris, M.; Wagner, E. Adv Drug Deliv Rev 1998, 30, 97-113. 